\title{
MATHEMATICAL AND ASSEMBLY MODELING OF THE MECHANISM FOR IMPLEMENTING INTERMITTENT ROTATIONAL MOTION AND SPEED SETTING OF THE METERING SHAFT FOR SEED DRILLS
}

\author{
Zoltán FORGÓ ${ }^{1}$, Ferenc TOLVALY-ROȘCA², Judit PÁSZTOR ${ }^{3}$ \\ Sapientia University, Faculty of Technical and Humanities Science, Mechanical \\ Engineering Department. Târgu Mureş, Romania \\ ${ }^{1}$ zforgo@ms.sapientia.ro \\ 2 tferi@ms.sapientia.ro \\ 3 pjudit@ms.sapientia.ro
}

\begin{abstract}
The metering shaft of the drilling machine is driven from the impeller. The standard traditional gearbox, the Norton gearbox, provides a constant rotating motion between the impeller and the metering shaft. Manufacturers have started to replace this gearbox with an intermittent rotating movement. Using the stepless variable speed gearbox, the speed of the metering shaft and thus the seed rate is set steplessly. The aim of the thesis is the mathematical modeling of the intermittent rotating motion of the seed drill of a particular drilling machine, and the creation of a striping model.
\end{abstract}

Keywords: intermittent rotating movement, oscillating swing arm cam mechanism, continuous seed drill drive.

\section{Introduction}

The seed drill places the seed into the ground in parallel rows and at different distances within a row, as discussed in the literature [2].

In the general construction of the drill there are the following: grain box, seeder system, seed tube, coulter, seeds covering harrow, row markers, wheels and driver, as written [2].

The seeder system performs the dosage and letting out of the seeds. The seeder systems are installed on a mutual shaft, the drill shaft. The drive of the drill shaft is provided by the land wheel. The drive of the drill shaft can be:

- Continuous, rotational motion: with change gears, drive gear, chain drive, Norton-type gearbox;

- Intermittent, rotational motion: with camrocker mechanism, as written $[4,5]$.

The traditional speed-gear of earlier drills is the Norton-type gearbox. This drive can achieve 72 speed grades, its functioning is safe, but it is of large size, and weight. Due to the gear wheels it is very expensive and it gathers dust, it corrodes, as written [8].

The ultimate aim is the adjustment of seed dosage within wide limits, providing 
more grades for letting out seeds. Wellknown international crop duster manufacturers began to equip their drills with a cam-rocker speed-gears. This is a speedgear functioning in a closed space, concealed from view in an oil-bath, Figure 1.

The following items can be found in the construction of the cam-rocker speed-gear: 1 power shaft; 2 driven, propelled shaft which is also the drill shaft and there is a one-way clutch and a feeding mechanism symbolically visualized; 3 rocker arm; 4 rocker; 5 cam; 6 roller; 7 supporting arch; 8 arresting lever for turning the supporting arch; 9 pre-stressed spring which supports the rocker on the arch.

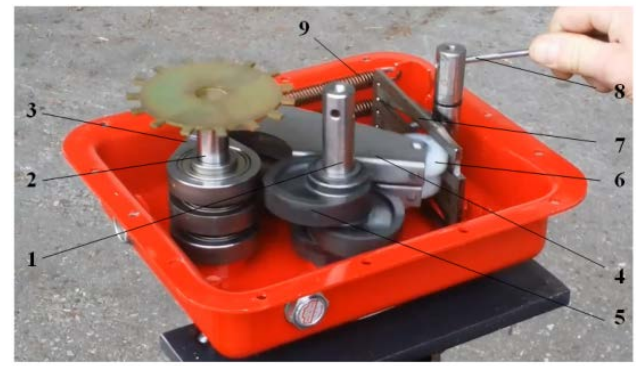

Figure 1. The construction of cam-rocker speedgear
In spite of its small size it is capable of selecting 100 or more speeds. Its functioning is smooth, the adjustment of the seed quantity is fast, continuously variable and it offers the possibility for automatization, as written [5, 6, 9].

In the present paper we study the intermittent rotational motion of the drill shaft drive. The method is analytical, it analyses an already existing structure, as written [1, 10]. The problem can be also solved by synthetic geometry since the structure of the mechanism, either equipped with cam gear or with excenters, is well determined mathematically

In our study we plan an assembly model on the basis of defining and studying the equation of motion. The assembly model helps visualization of the effects of adjusting the seed quantity of the drill shaft.

\subsection{The construction of speed-gear implementing intermittent rota- tional motion}

The studied metering shaft for seed drill provides an intermittent rotary motion by using a rocking arm excenter mechanism.

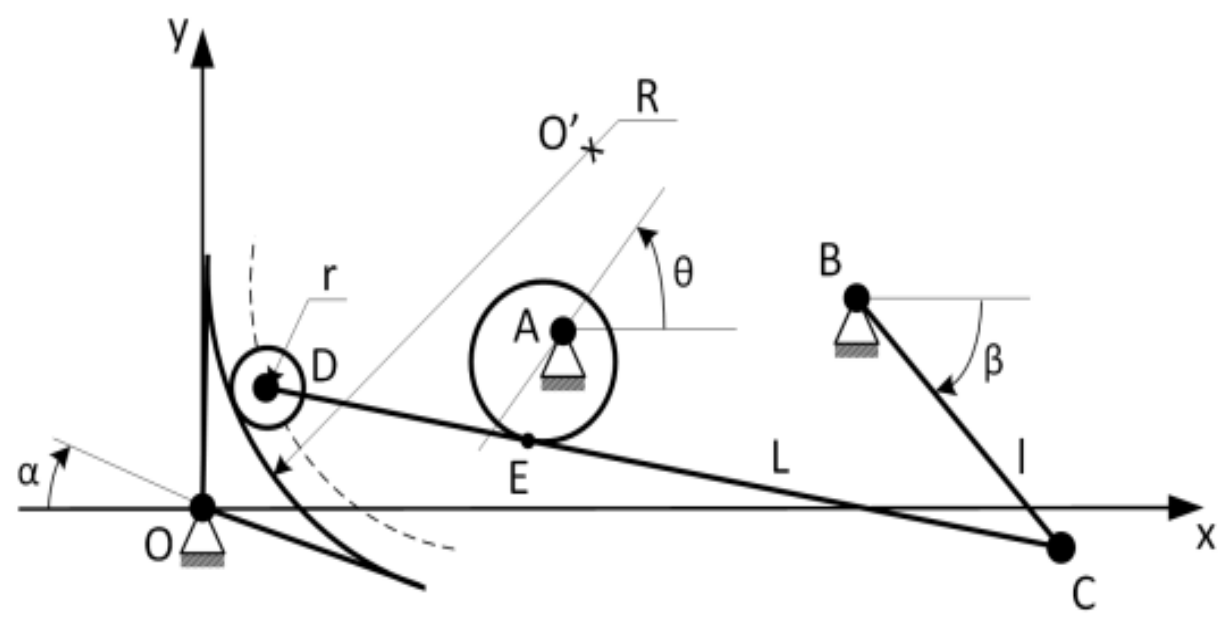

Figure 2. The kinematic sketch of the rocker arm mechanism 
The kinematic sketch is shown on Figure 2 and consists of: A-power shaft, $B$ propelled shaft, $B C$-rocker arm, $D C$-rocker, $E$-excenter, $D$-roller, $O$ '-supporting arch.

The supporting arch provides the support for the power shaft to be rotated by a $\beta$ angle.

\subsection{The operation of the speed-gear implementing intermittent rota- tional motion}

The impeller provides the continuous rotary motion to the power shaft, $A$, of the speed-gear implementing intermittent rotational motion. The excentre keeps the rocker $D C$ rocking that moves the rocker arm, and through a one-way clutch the intermittent rotary motion is transmitted to the metering shaft. The output shaft is the driven shaft which is also the metering shaft. The rocker is supported by an arch with spring, but it is not shown on the kinematic figure.

The propelled shaft maximum rotating angle influences the speed of the metering shaft, thus indirectly influencing the number of distributed seeds. The rocking motion can be influenced by the rotation of the supporting arch, which influences the active length of the rocker. The position change of the supporting arch is achieved by an arm and measured on a scale. Thus, the scale alongside with a table provided by the manufacturer indicates the amount of seed distributed.

\section{Mathematical modeling of the} speed-gear implementing intermittent rotational motion

The main objective is to determine a formula for angle $\beta$ as a function of $\theta$ angle, Figure 2.

We studied the mechanism with a geometric method, by determining the positions of points $D, C$ and $E$, as written [7].
The geometrical location of point $D$ is expressed by formula (1):

$$
\left(x_{D}-x_{O^{\prime}}^{\alpha}\right)^{2}+\left(y_{D}-y_{O^{\prime}}^{\alpha}\right)^{2}=(R-r)^{2} \text {, }
$$

where: $R$ is the radius of the supporting arch, $r$ is the radius of the roller, $D$ is the center point of the roller, $O$ ' is the center point of the supporting arch.

The geometrical location of point $C$ :

$\left(x_{C}-x_{B}\right)^{2}+\left(y_{C}-y_{B}\right)^{2}=l^{2}$,

where: $l$ is the length of the rocker arm.

The geometric location of point $E$ :

$\left(x_{E}-x_{A}-e \cos \theta\right)^{2}+\left(y_{E}-y_{A}-\right.$

$e \sin \theta)^{2}=r_{A}^{2}$,

where: $A$ is the center point of the power shaft, $E$ is the contacting point of the excentre and the rocker, $r_{A}$ is the center point of the excentre, $e$ is the excentricity, $\theta$ angle describes the momentary position of the power shaft.

Formula (4) is produced by the collinearity of points $C, D$ and $E$ :

$\left(x_{C}-x_{D}\right)\left(y_{E}-y_{D}\right)-\left(y_{C}-y_{D}\right)\left(x_{E}-\right.$

$\left.x_{D}\right)=0$

The distance between points $C$ and $D$ is constant, and symbolized by $L$ :

$\left(x_{C}-x_{D}\right)^{2}+\left(y_{C}-y_{D}\right)^{2}=L^{2}$.

Sections $D C$ and $E A$ are perpendicular, thus:

$\left(y_{D}-y_{C}\right)\left(y_{E}-y_{A}\right)-\left(x_{D}-x_{C}\right)\left(x_{E}-\right.$

$\left.x_{A}\right)=0$.

The mathematical model produces the position of the metering shaft.

Figure 3 shows the driven components position as a function of time, based on the mathematical model. 


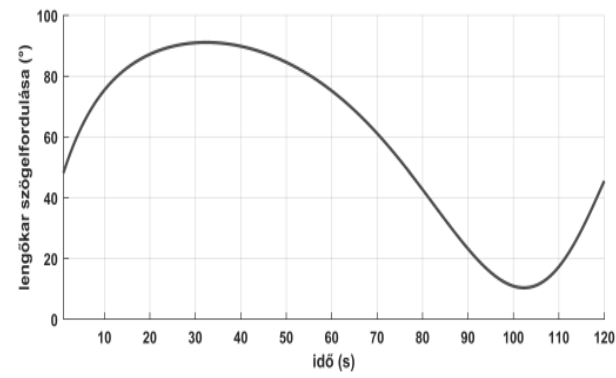

Figure 3. The rocker arm position

The ascending part of the plot allows the rotation of the metering shaft, whereas a one-way clutch does not allow the transmission of the movement to the metering shaft on the descending part of the plot.

The velocity of the rocker arm is determined by geometric method also, with graphical derivation, Figure 4.

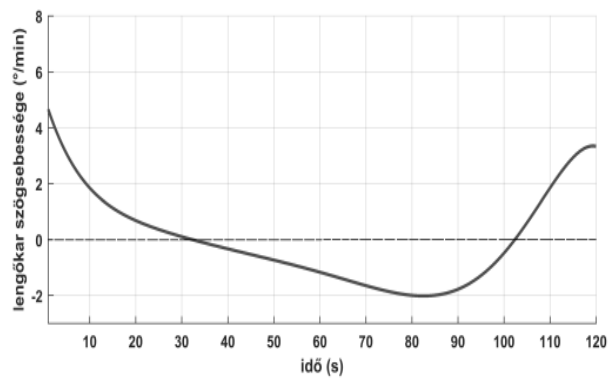

Figure 4. Velocity of the rocker arm

In the case of positive velocity values of the rocker arm, as shown in Figure 4, the eccentric shaft 2 executes a rotating motion. For the negative velocity values, the eccentric shaft remains stationary.

Studying the plot reveals that the velocity of the metering shaft is not constant and a shock effect appears on the beginning of the rotation.

In order to provide a constant rotation of the metering shaft, manufacturers apply multiple rocker arms. Figure 5 shows the results on the position and velocity of the metering shaft when 3 rocker arms were coupled in series, with a phase shift in excentricity.
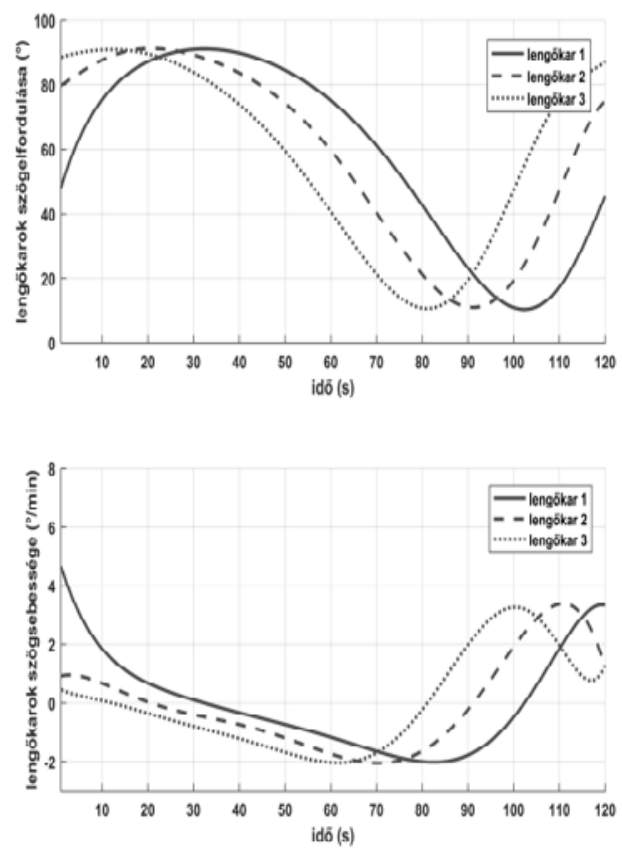

Figure 5. Position and velocity of three rocker arms coupled in series

The sum of the velocity of the rocker arms shows a velocity increase in the beginning of the rotation, whereas the velocity becomes constant as all the rocker arms start their movement. The constant speed of the metering shaft has a beneficial effect on the seeds' distribution.

\section{Assembly model of the speed- gear implementing intermittent rotational motion}

Figure 6 shows the assembly model based on the movement equations.

The assembly model is based on the dimensions of the Bomet $m$ 2,7x21 speedgear. The operation of the excentric rocker arm gearbox is the following: the power shaft, 1 , transmits the motion through the excentre, 2, to the rocker, 3 . 


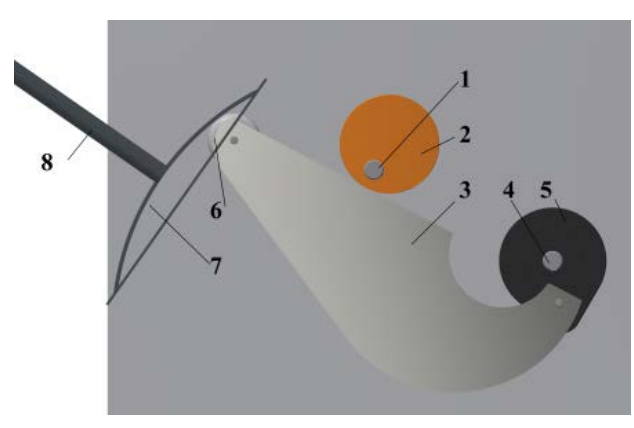

Figure 6. The assembly model

The rocker moves the rocker arm, 5, through which a one directional intermittent rotary motion is produced with the help of a one-way clutch on the driven, metering shaft, 4 . The other side of the rocker is supported by the arch, 8 , through the roller, 6 . The supporting arch can be moved by an arm, 8 , influencing the position of the rocker, thus the rotating angle of the rocker arm, thus the speed of the metering shaft. The seed amount that gets distributed is influenced by the position of the $8 \mathrm{arm}$.

The constrain that connects the supporting arch and the roller acts as an arc assuring continuous contact between them.

The speed of the metering shaft is influenced by the kinematic parameters of the mechanism, the excentricity, the active length of the rocker and the position of the supporting arch.

\section{Conclusions}

The cam rocker speed-gears simplify the construction and operation of the engine, and reduce the preliminary cost. The adjustments can be made very easily, in a continuously variable way, following the scale and the chart. This is the reason why they are more often built in the drill.

With the help of the created mathematical models, the effect of the parameters on the speed of the drill shaft can be studied.
The mathematical models are suitable for comparison and realization of new solutions.

Manufacturers place more cams on the power shaft in order to make the intermittent rotational motion smoother. The implemented mathematical models are suitable for studying the effect of several excenters in order to find the optimal functioning of the seed drill shaft.

It would be worth studying the possibility that the rotation of the drill shaft and the rocking arm is in the constant speed range.

The implemented model illustrates the motion of the drill shaft speed gear with rocking arm. It simplifies understanding of the mechanism of the drill shaft speed gear.

\section{Bibliography}

[1] Erdman A. G., Sandor G. N.: Mechanism design: analysis and synthesis. Prentice Hall PTR, New Jersey, 1984, 49-64.

[2] A zöldség-, dísznövény- és szaporítóanyag termesztés berendezései és gépei. (ed.: Láng Z.) Mezőgazda Kiadó, Budapest, 1999.

[3] Loghin Fl.: Acţionarea intermitentă a aparatelor de distribuţie ale maşinilor de semănat universal - The intermitent action of the machines of distribution of universal broadcast seeder. INMATEH - Agricultural Engineering 18/3. (2006) 231-237.

[4] Loghin Fl., Rus Fl.: Theoretical modeling through virtual prototyping of transmission of sowing machines. In: Research People And Actual Tasks On Multidisciplinary Sciences Lozenec, Bulgaria, 2. (2011) 52-57.

[5] Loghin Fl.: Contribuţii privind cinematica şi dinamica transmisiilor $\mathrm{cu}$ mişcare intermitentă ale maşinilor de semănat universale Contributions regarding the kinematics and the dynamics of transmissions with intermitent motion of universal seed drills. Summary of PhD Thesis, Universitatea Transilvania, Brasov, 2010, 35-58.

http://webbut.unitbv.ro/teze/rezumate/2010/r om/FlorinLoghin.pdf

[6] Manea D., Voicu Gh., Paraschiv G., Marin E.: Theoretical researches on kinematics of cam - rocker mechanisms from seed drills transmission. Universitatea Politehnică 
București. Scientific Bulletin Series D Mechanical Engineering, 78/2. (2016) 199210.

[7] Máté M.: Müszaki mechanika - kinematika. EME Publisher, Cluj-Napoca, 2010. https://eda.eme.ro/handle/10598/15439

[8] Naghiu Al.: Maşini şi instalaţii agricole I. Risoprint, Cluj-Napoca, 2004, 369-371.

[9] Marin E., Cherciu D., Păun A., Cheptea C., Manea D., Istrate B., Gheorghe G., Mateescu M., David A., Neacşu F.: Parametric modeling of the impulse gearbox in oil bath from the grasslands regeneration machine / Modelarea parametrică a cutiei de viteze cu impulsuri în baie de ulei de la maşina de regenerat pajistit. In: ISB-INMA the Agricultural and Mechanical Engineering, București, 2015, 67-72.

http://isb.pub.ro/wp-content/isbinmateh/2015/ Volume_Symposium_2015.pdf

[10] Pelecudi Chr., Maros D., Merticaru V., Pandrea N., Simionescu I.: Mecanisme, Editura Didactică și Pedagogică, București, 1985, 71-109. 